\title{
Association of morphometric measurements with morphologic scores of Criollo horses at Freio de Ouro: a path analysis
}

\section{Anelise Maria Hammes Pimentel ${ }^{1}$, João Ricardo Malheiros de Souza ${ }^{2^{*}}$ (iD, Arione Augusti Boligon', Heden Luiz Marques Moreira ${ }^{3}$, Sandra Mara da Encarnação Fiala Rechsteiner ${ }^{3}$, Cláudio Alves Pimentel ${ }^{4}$, Charles Ferreira Martins ${ }^{5}$}

\footnotetext{
1 Universidade Federal de Pelotas, Faculdade de Agronomia Eliseu Maciel, Departamento de Zootecnia, Campus Capão do Leão, Capão do Leão, RS, Brasil.

2 Universidade Federal de Santa Maria, Programa de Pós-graduação em Medicina Veterinária, Santa Maria, RS, Brasil.

3 Universidade Federal de Pelotas, Instituto de Biologia, Campus Capão do Leão, Capão do Leão, RS, Brasil.

4 Universidade Federal de Pelotas, Faculdade de Veterinária, Departamento de Patologia Animal, Campus Capão do Leão, Capão do Leão, RS, Brasil.

${ }^{5}$ Universidade Federal de Pelotas, Faculdade de Veterinária, Departamento de Clínicas Veterinária, Campus Capão do Leão, Capão do Leão, RS, Brasil.
}

\begin{abstract}
This study used path analysis to establish the direct, indirect, and total effects of body linear and angular measurements on subjective morphological scores of the 247 Criollo horses that participated in their most important performance event, Freio de Ouro, in 2012. Freio de Ouro is the only event of the Criollo breed that considers morphology. Measurements of wither height, thoracic girth, cannon bone girth, body length, metatarsus length, croup length, shoulder width, head length, neck length, and upper neck girth, and the angles of rump, shoulder, and hock were taken. These morphometric measurements collectively explained $83 \%$ of the variation in morphological score. The measurements with the greatest total effects on score were neck length (correlation coefficient $=0.2300)$, upper neck girth $(0.2100)$, angle of rump $(-0.1600)$, thoracic girth $(0.1400)$, shoulder width $(0.1400)$, body length $(0.1100)$, croup length $(0.1100)$, shoulder angle $(-0.1100)$, and metatarsus length $(0.1000)$. These results mean that these variables have the highest association with morphological evaluation by referees. This is the first scientific study of the correlation of morphological measurements with judge evaluation in Criollo horses.
\end{abstract}

Key Words: animal production, Criollo, equine, morphometry, path analysis

\section{Introduction}

Criollo horse is among the most populous horse breeds in Brazil, and its socioeconomic importance to the Brazilian equine culture is obvious, as it is largely responsible for the growth and popularization of equine sports in Brazil (Lima and Cintra, 2015). Since its foundation in 1932, the Associação Brasileira de Criadores de Cavalos Crioulos (ABCCC) has held expositions in which animals are judged for their conformation to the morphological standards established by a breeder group; these standards are based on the criteria used in other countries, such as Uruguay and Argentina. Over time, the lack of agility of these Criollo horses has discouraged cattle ranchers and farmers, leading to a desire for and pursuit of more functional horses. In

Received: January 24, 2018

Accepted: April 24, 2018

*Corresponding author: joao.rms@gmail.com

Copyright $(2018$ Sociedade Brasileira de Zootecnia. This is an Open Access article distributed under the terms of the Creative Commons Attribution License (http://creativecommons.org/licenses/by/4.0/), which permits unrestricted use, distribution, and reproduction in any medium, provided the original work is properly cited.
1978, the first functional competition was held in the municipality of Jaguarão, RS. This competition culminated in the creation of the Freio de Ouro competition in 1982, which aimed at the improvement and appreciation of functional horses (Affonso and Correa, 1992; Dalto, 2006).

The judgment at Freio de Ouro, as it has been since the beginning, takes into account conformation characteristics, in which a score for horse morphology is added to the functional performance only at the end of the competition, to avoid invalidating the breed standard certification and other morphological characteristics that formed the foundation of the breed (ABCCC, 2015). The morphological and functional evaluations are carried out by three referees selected by the Technical Deliberative Council. The morphological evaluation is the result of subjective observations of many different body parts, in which all details should collectively present harmony, nobility, and typicality for the breed (Souza, 1998). The criteria implemented by the referees to determine the morphological score are the same as used for the evaluation at morphological expositions of the Criollo breed to 
standardize the selection for breeding (ABCCC, 2016), although no score is assigned in the latter evaluations. The weight of the morphological score, in credentialing tests as well as the qualifying round and finals of Freio de Ouro, represents $37.2 \%$ of the final overall score (Dalto, 2006), highlighting the importance of morphology in the results of the competition. This results in a desire for horses with good morphology scores. The Freio de Ouro is the only competition that considers morphology.

The morphological evaluations are always a great public attraction. A study published by ABCCC identified that, of the factors considered in horse acquisition, more than $75 \%$ of interviewees stated that morphological beauty, independent of the breed, was the most important item, followed by, with less intensity, genealogy, temperament, coat/hair, breed, and other characteristics (ABCCC, 2014).

Three objective measures are used by $\mathrm{ABCCC}$ for registration purposes: wither height, thoracic girth, and cannon bone girth. Males must have a height ranging from 140 to $150 \mathrm{~cm}$, a minimum thoracic girth of $168 \mathrm{~cm}$, and a minimum cannon bone girth of $18 \mathrm{~cm}$. For females, the height ranges from 138 to $148 \mathrm{~cm}$, and minimum thoracic and cannon bone girths are $170 \mathrm{~cm}$ and $17 \mathrm{~cm}$, respectively (ABCCC, 2016). Other morphologic virtues and defects are evaluated subjectively. This approach is also used for evaluating other breeds (Mawdsley et al., 1996; Beeman, 2008; Lage et al., 2009).

With the introduction of Chilean bloodlines in the 1970s, there have been morphological modifications to the Criollo breed; for example, the previous square-shaped body was replaced by the current rectangular shape, although this might be a perception due to variability in subjective morphological evaluations rather than a true change. The present study was performed to determine the magnitudes of the associations of linear and angular morphological measurements with the most subjective morphological scores given by the referees to the horses attending the Freio de Ouro. This work is the first report on this subject. It provides scientific data and consistent tools to horse referees, technicians, and breeders and contributes to standardization of morphological evaluations in Criollo horses.

\section{Material and Methods}

This study was approved by the local Ethics and Welfare Committee (CEEA), under case no. 3.943. All techniques used in this study were non-invasive.

This study used data from 247 Criollo horses (124 females and 123 males) with mean age of $7.3 \pm 1.7$ years and mean weight of $430 \pm 24.8 \mathrm{~kg}$, measured during the qualifying and final events of Freio de Ouro competition in 2012. The work was performed in cities of the following states: Rio Grande do Sul (Esteio, Pelotas, Santa Rosa, Cachoeira do Sul, Caxias do Sul, and Carazinho), Santa Catarina (Lages), Paraná (Maringá), and Distrito Federal (Brasília) in Brazil. Linear measurements of withers height, thoracic girth, cannon bone girth, body length, metatarsus length, croup length, shoulder width, head length, neck length, upper neck girth, and the angles of rump, shoulder, and hock were taken on the left side of the standing animal, with all four legs on a horizontal and even floor. These measurements are described in Pimentel et al. (2018).

Height, thoracic girth, and cannon bone girth measurements were taken by $\mathrm{ABCCC}$ technicians, and the other measurements were taken by a trained member of the research team. Morphological scores were given by referees at the beginning of the competition and were provided by the ABCCC for this study. The referees initially judged from the ground, and the animals were led by halters.

Descriptive and path analyses (Cruz et al., 2004) were conducted using R software (R Core Team, 2016). Path analysis was performed to determine the direct, indirect, and total effects that the morphometric measures (explanatory variable) had on the morphological scores (principal variable) of referees. This analysis, developed by Wright (1921), is a method used to illustrate and explain the associations between different characteristics and to classify the correlations among them as direct and indirect effects.

\section{Results}

The morphometric measurements (Table 1) explained $83 \%\left(\mathrm{R}^{2}=0.83\right)$ of the variation in the morphologic score. None of the associations were high, and neck length showed the highest direct and total effects (correlation coefficients of 0.2301 and 0.2300 , respectively) on the morphological score (Table 2) with no indirect effect, indicating that the effects of other variables were not responsible for the magnitude of correlation.

\section{Discussion}

According to the breed standard, the neck should be tightly coupled to a large head by a large and clean upper neck, the upper edge slightly convex, with thick and abundant mane, almost straight in its inferior line with broad, strong, muscles with harmonic insertion to the thorax and median in length. In the horses attending 
Table 1 - Mean and standard deviation (SD) of the morphometric measurements obtained from 247 Criollo horses evaluated during the qualifying and final events of Freio de Ouro competition in 2012, by sex (123 males and 124 females)

\begin{tabular}{|c|c|c|c|c|c|c|}
\hline \multirow{2}{*}{ Linear variable } & \multicolumn{2}{|c|}{ Total } & \multicolumn{2}{|c|}{ Males } & \multicolumn{2}{|c|}{ Females } \\
\hline & Mean $(\mathrm{cm})$ & SD & Mean $(\mathrm{cm})$ & $\mathrm{SD}$ & Mean $(\mathrm{cm})$ & SD \\
\hline Whiter height & 141.52 & 1.92 & 141.61 & 1.59 & 141.42 & 2.19 \\
\hline Thoracic girth & 176.41 & 3.56 & 175.53 & 3.48 & 177.27 & 3.45 \\
\hline Cannon bone girth & 19.52 & 0.79 & 19.97 & 0.66 & 19.08 & 0.64 \\
\hline Body length & 164.40 & 4.84 & 163.62 & 4.30 & 165.15 & 5.22 \\
\hline Metatarsus length & 20.71 & 1.03 & 20.68 & 1.05 & 20.74 & 1.02 \\
\hline Croup length & 56.73 & 2.9 & 56.87 & 3.03 & 56.60 & 2.78 \\
\hline Shoulder width & 40.95 & 1.82 & 41.43 & 1.58 & 40.49 & 1.92 \\
\hline Head length & 63.99 & 2.38 & 64.37 & 2.63 & 63.60 & 2.05 \\
\hline Neck length & 78.23 & 4.91 & 79.14 & 4.67 & 77.33 & 4.99 \\
\hline Upper neck girth & 74.77 & 4.18 & 77.17 & 3.41 & 72.43 & 3.48 \\
\hline Angular variable & Mean $\left(^{\circ}\right)$ & SD & Mean $\left(^{\circ}\right)$ & $\mathrm{SD}$ & Mean $\left(^{\circ}\right)$ & $\mathrm{SD}$ \\
\hline Rump angle & 21.65 & 4.48 & 21.64 & 3.96 & 21.66 & 4.95 \\
\hline Shoulder angle & 60.51 & 5.23 & 59.44 & 5.15 & 61.55 & 5.17 \\
\hline Hock angle & 152.18 & 5.01 & 152.00 & 5.51 & 152.37 & 4.49 \\
\hline
\end{tabular}

Table 2 - Correlation coefficients between morphometric measurements and subjective morphological score

\begin{tabular}{lrrr}
\hline \multirow{2}{*}{ Variable } & \multicolumn{3}{c}{ Effect } \\
\cline { 2 - 4 } & Direct & Indirect & Total \\
\hline Withers height & 0.0167 & 0.0633 & 0.0800 \\
Thoracic girth & 0.0990 & 0.0410 & 0.1400 \\
Cannon bone girth & -0.1376 & 0.1576 & 0.0200 \\
Body length & 0.1092 & 0.0008 & 0.1100 \\
Metatarsus length & -0.0118 & 0.1118 & 0.1000 \\
Croup length & 0.0005 & 0.1095 & 0.1100 \\
Shoulder width & 0.0644 & 0.0756 & 0.1400 \\
Head length & -0.1063 & 0.0663 & -0.0400 \\
Neck length & 0.2301 & -0.0001 & 0.2300 \\
Upper neck girth & 0.1825 & 0.0275 & 0.2100 \\
Rump angle & -0.1982 & 0.0382 & -0.1600 \\
Shoulder angle & -0.1180 & 0.0080 & -0.1100 \\
Hock angle & -0.0417 & 0.0717 & 0.0300 \\
Coefficient of determination & & $\mathrm{R}^{2}=0.8287$ \\
\hline
\end{tabular}

Freio de Ouro, the average neck length was $79.14 \pm 4.67$ and $77.33 \pm 4.99 \mathrm{~cm}$ for males and females, respectively (Table 1). Neck length is a measurement highly associated with morphologic beauty in the Árabe breed, which has a similar neck length of $78.2 \mathrm{~cm}$ (Sobczuk and Komosa, 2012). Adults of the Mangalarga Marchador breed had a shorter mean neck length of $65.0 \mathrm{~cm}$ (Cabral et al., 2004). The neck also has an important function in the action of the anterior limbs; the neck musculature controls the action of the muscles of the shoulder, arm, and forearm, leading to more powerful movements in the front legs (Santiago, 2013; Denoix, 2014).

The upper neck girth, which should be large and clean according to the breed standard, also showed a positive correlation with morphological score, with a correlation coefficient of 0.1825 for the direct effect and 0.2100 for the total effect. In addition, upper neck girth was positively influenced by the other measurements (indirect effect), mainly by longer neck length (results not shown). The mean general measurement for upper neck girth was $74.77 \mathrm{~cm}$, and males had a slightly thicker upper neck than females (Table 1). According to Souza (1998), the neck has to be coupled to the head in a clean and strong manner, demonstrating support and allowing balanced movement.

Rumps with a lower angle, that is, rumps that are more horizontal, were more valued morphologically; rump angle had a direct effect of -0.1982 and total effect of -0.1600 , with an indirect effect that was mainly through neck length. The mean rump angle was $21.65^{\circ}$ (Table 1), which is close to the values in Pons and Pons (2016), who reported an inclination of rump angle of $23^{\circ}$ in the Criollo breed, but lower than the value of $30^{\circ}$ in Criollo horses cited by Dowdall (1982). This result suggests that in the last few decades, the rump has become less inclined (more flattened). This was also observed by Pimentel et al. (2018) in adult Criollo horses attending Freio de Ouro, in which younger animals, up to seven years of age, had a tendency to lower rump angles $\left(21.9^{\circ}\right)$ than animals aged more than seven years $\left(22.7^{\circ}\right)$, showing a trend in the valuation of animals with more horizontal rumps.

The direct effect of croup length was nearly zero (Table 2), and its indirect effects, through body length and neck length, were stronger. Thus, indirect effects were responsible for the overall correlation between croup length and morphological score (total effect of 0.1100). According to breed standards, the croup should be muscular, strong, well-developed, slightly inclined, and of medium length. The mean croup length of $56.73 \mathrm{~cm}$ (Table 1) obtained in the present study is similar to the value of $55.05 \mathrm{~cm}$ reported 
for cutting line Quarter Horses (Meira et al., 2013), which execute movements very similar to those executed by Criollo horses in the Freio de Ouro competition. On the other hand, in racing line Quarter Horses, Meira et al. (2013) reported that the croup length was significantly larger, with value of $62.03 \mathrm{~cm}$. These results suggest that there is a particular form that will favor one or another function. Sobczuk and Komosa (2012) showed that a long croup has a significant positive impact on motor performance and speed tests.

There was a small positive association of thoracic girth with morphological score, with a direct effect correlation of 0.0990 and a total effect correlation of 0.1400 , but there was little influence by indirect effects. The mean thoracic girth of the horses attending Freio de Ouro was $176.41 \mathrm{~cm}$, meeting the breed standards of a minimum length of $170 \mathrm{~cm}$ for females and $168 \mathrm{~cm}$ for males. These measurements are slightly lower than those of Kurtz Filho and Löf (2007), who worked with Criollo horses in conformation competitions and found a mean thoracic girth of $180 \mathrm{~cm}$ for females and $179 \mathrm{~cm}$ for males. The greater thoracic girth obtained by those authors may be related to the fact that the evaluated animals were prepared for morphological competition with a trend toward greater fat accumulation and, for the most part, not prepared for functional tests.

Several authors agree that horses with reduced thoracic girth have less physical force (Torres and Jardim, 1987; Zamborline et al., 1996; McManus et al., 2005). According to Lage et al. (2009), a greater thoracic girth is associated with genetic, nutritional, and conditioning factors. Genetic factors significantly influenced morphometric measurements in Quarter horses, in which racing lineages had a larger thoracic girth, at $196.7 \mathrm{~cm}$, than did working lineages, which had a mean thoracic girth of $180.2 \mathrm{~cm}$ (Meira et al., 2013).

Animals with greater chest width had higher morphological scores, so the total effect of this measurement was positive (0.1400); this was due to both direct and indirect effects, each of which contributed little on its own (Table 2). The chest width of this breed has a mean value of $40.95 \mathrm{~cm}$ (Table 1).

As for the shoulder angle, there were negative direct $(-0.1180)$ and total $(-0.1100)$ effects on the morphological scores. More horizontal shoulders were more valued morphologically. The general mean of the shoulder angle of this breed is $60.51^{\circ}$ (Table 1), although Dowdall (1982) reported a smaller shoulder angle, around $50^{\circ}$, for this breed. According to Souza (1998), larger angles, or more vertical shoulders, decrease the length of the step and make walking uncomfortable, because, according to Jones (1987), a more horizontal shoulder absorbs better the impact generated by the contact of the hoof with the ground, resulting in a greater damping and softness during movement. According to Souza (1998), horses with a compact front and vertical shoulders that result in small steps and have small thoracic girth are uncomfortable and unstable.

There were positive direct $(0.1092)$ and total $(0.1100)$ effects of body length on morphological score, in which longer animals were scored higher by referees. The mean body length was $163.62 \mathrm{~cm}$ and $165.15 \mathrm{~cm}$ for males and females, respectively (Table 1). Morphology has been studied in other Brazilian saddle breeds originating from Berber horses, similar to the Criollo breed, and, in all, the body is shorter than that of Criollo (Cabral et al., 2004; McManus et al., 2005; Ramos et al. 2014). The Quarter breed has a body length of about 149.52 (Meneses et al., 2014) and $150.43 \mathrm{~cm}$ (Ramos et al., 2014). According to Meira et al. (2013), racing Quarter horses have greater body length than do working lineages, at 180.8 and $163.4 \mathrm{~cm}$, respectively, showing that there is a different appropriate body type for each modality. The mean body length obtained in the present study for Criollo horses in the Freio de Ouro competition $(164.4 \mathrm{~cm})$ was similar to the value reported for working lineage Quarter Horse (Meira et al., 2013), whose abilities in the functional tests are similar, as well as to demonstrate that shorter animals allow greater agility in laterality movements.

Although there was nearly no direct effect of metatarsus length (Table 2), there was a positive correlation with the morphological score, with a total effect of 0.1000 and an indirect effect of 0.1118 due to correlations with other variables, mainly neck length (results not shown). The mean metatarsus length in this breed is $20.71 \mathrm{~cm}$ (Table 1), a value lower than that documented by Dowdall (1982) of $27 \mathrm{~cm}$, which shows a change over the last few decades. Although a decrease in length has been observed, longer metatarsus leads to better morphological scores. According to Sobczuk and Komosa (2012), longer metatarsus is associated with higher motor efficiency, especially greater predisposition to galloping and, according to Meneses et al. (2014), allow for quicker turns and abrupt stops.

While the withers height in the animals attending Freio de Ouro was close to the minimum requirement of the breed standard, with means of $141.61 \mathrm{~cm}$ in males and $141.42 \mathrm{~cm}$ in females (Table 1), this measurement did not show a correlation with morphological score (Table 2). This result can be attributed to the low variability of this value and to the fact that harmony and balance between the different parts of the body are more important in the 
general evaluation of the animal; thus, height is a small factor in the overall score.

About $45 \%$ of the animals had a morphological score above the general mean $(6.83 \pm 0.49)$, ranging from 5.86 to 9.80. On average, the morphological score was apparently higher for females $(6.84 \pm 0.58)$ than for males $(6.82 \pm 0.41)$. It was expected that the males would be better scored due to the higher selection intensity applied in this category, since these animals are subjected to full evaluations by ABCCC technicians, while females must only reach the minimum measurements required by the breed standard to be confirmed. In general, this result suggests the possibility of extinction of male conformations, which, according to Pons and Pons (2016), are believed to be a desire of several breeders but have little or no role in the selection process. Technicians should identify the males with high animalperformance value on the property and guide breeders to castrate animals with low potential for breed improvement, avoiding their use in breeding, which also reduces the costs of feeding, examinations, and transport to these events. These animals can participate and compete in other sports that do not require morphological beauty, as well as for leisure, for which demand is growing as people seek out horses and nature to reduce stress and improve their quality of life, particularly in large urban centers.

The concept of perfect conformation varies from breed to breed, but there is a consensus that morphological beauty consists in bringing together all parts of the body in a harmonic and symmetrical way, proportional to the size of the body (Ensminger, 1978; Torres and Jardim, 1987; Souza, 1998; McManus et al., 2008). In the present study, it was found that some body characteristics (neck length, thoracic girth, body length, croup length, and rump angle) have greater influences on the subjective morphological scoring of referees, providing objective information for making decisions during competitions, and valuable auxiliary information for the breeding-selection process for Criollo horses.

\section{Conclusions}

Through path analysis, we found low-magnitude correlations between explanatory variables (morphometric measurements) and subjective morphological score of Criollo horses. Animals with longer necks, larger upper necks, greater thoracic girth, longer body length, longer croups, wide shoulders, and more horizontal rumps and shoulders were given higher morphological scores by the referees. Females had higher morphological scores than males. The results of this work represent an important tool for technicians, referees, and breeders to use when selecting individual Criollo horses.

\section{Acknowledgments}

The authors thank the Associação Brasileira de Criadores de Cavalos Crioulos (ABCCC), for the financial and technical support, and Dr. Gabriel de Marco Flório, Dr. Ibsen Votto, Dr. Rodrigo Teixeira, Dr. Mário Móglia Suñe, and Dr. Manuel Luís Benevenga Sarmento, for assistance in data collection.

\section{References}

ABCCC - Associação Brasileira de Criadores de Cavalos Crioulos 2014. Anuário da raça Crioula 54(51).

ABCCC - Associação Brasileira de Criadores de Cavalos Crioulos. 2015. Regulamento Freio de Ouro. Associação Brasileira dos Criadores de Cavalos Crioulos, Pelotas.

ABCCC - Associação Brasileira de Criadores de Cavalos Crioulos. 2016. Regulamento do serviço de registro genealógico e regulamento do registro de mérito. Associação Brasileira de Criadores de Cavalos Crioulos, Pelotas.

Affonso, A. and Correa, S. 1992. Cavalo Crioulo: uma história de raça. Sagra, Porto Alegre.

Beeman, G. M. 2008. Conformation of the horse: relationship of form to function. p.63-68. In: Annual Convention of the American Association of Equine Practitioners. AAEP, San Diego, CA.

Cabral, G. C.; Almeida, F. Q.; Quirino, C. R.; Pinto, L. F. B.; Santos, E. M. and Corassa, A. 2004. Avaliação morfométrica de equinos da raça Mangalarga Marchador: medidas lineares. Revista Brasileira de Zootecnia 33:989-1000. https://doi.org/10.1590/S1516-359820 04000400019

Cruz, C. D.; Regazzi, A. J. and Carneiro, P. C. S. 2004. Modelos biométricos aplicados ao melhoramento genético. 3.ed. Universidade Federal de Viçosa, Viçosa, MG.

Dalto, R. 2006. Freio de Ouro: uma história a cavalo. Associação Brasileira de Criadores de Cavalos Crioulos, Santa Maria.

Denoix, J. M. 2014. Biomechanics and physical training of the horse. CRC Press, Boca Raton, FL.

Dowdall, R. C. 1982. Criando Criollos. Hemisferio Sur, Montevideo.

Ensminger, M. E. 1978. Produccion equina. Libreria El Ateneu, Buenos Aires.

Jones, W. E. 1987. Genética e criação de cavalos. Roca, São Paulo, SP.

Kurtz Filho, M. and Löf, H. K. 2007. Biometric in Brazilian Criollo horse breed. Archives of Veterinary Science 12:47-51

Lage, M. C. G. R.; Bergmann, J. A. G.; Procópio, A. M.; Pereira, J. C. C. and Biondini, J. 2009. Associação entre medidas lineares e angulares de equinos da raça Mangalarga Marchador. Arquivo Brasileiro de Medicina Veterinária e Zootecnia 61:968-979. https://doi.org/10.1590/S0102-09352009000400027

Lima, R. A. S. and Cintra, A. G. 2015. Revisão do estudo do complexo do agronegócio do cavalo. Ministério da Agricultura, Brasília, DF.

Mawdsley, A.; Kelly, E. P.; Smith, F. H. and Brophy, P. O. 1996. Linear assessment of the Thoroughbred horse: an approach to conformation evaluation. Equine Veterinary Journal 28:461-467.

McManus, C.; Falcão, R. A.; Spritze, A.; Costa, D.; Louvandini, H.; Dias, L. T.; Teixeira, R. A.; Rezende, M. J. M. and Garcia, J. A. S. 2005. Caracterização morfológica de equinos da raça Campeiro. Revista Brasileira de Zootecnia 34:1153-1562. https://doi.org/ 10.1590/S1516-35982005000500015 
McManus, C.; Santos, S. A.; Silva, J. A.; Louvandini, H.; Abreu, U. G. P.; Sereno, J. R. B. and Mariante, A. S. 2008. Body indices for the Pantaneiro horse. Brazilian Journal Veterinary Research Animal Science 45:362-370.

Meira, C. T.; Curi, R. A.; Silva, J. A. V.; Corrêa, M. J. M.; Oliveira, H. N. and Mota, M. D. S. 2013. Morphological and genomic differences between cutting and racing lines of Quarter Horses. Journal Equine Veterinary Science 33:244-249. https://doi.org/ 10.1016/j.jevs.2012.07.001

Meneses, A. C. A.; Costa, M. D.; Maruch, S.; Moreira, P. R. and Martins Neto, T. 2014. Medidas lineares e angulares de animais da raça Quarto de Milha utilizados em uma prova de vaquejada. Revista Brasileira Ciência Veterinária 21:256-261.

Pimentel, A. M. H.; Souza, J. R. M.; Boligon, A. A.; Moreira, H. L. M.; Pimentel, C. A. and Martins, C. F. 2018. Biometric evaluation of Criollo horses participating in the Freio de Ouro competition, Brazil. Revista Brasileira de Zootecnia 47:e20170294. https://doi. org/10.1590/rbz4720170294

Pons, D. S. and Pons, F. D. 2016. O Cavalo Crioulo: evolução no tempo. Grupo Futura, Porto Alegre.

Ramos, T. N. M.; Cardoso, D.; Oliveira, J. V. and Bomfim, C. A. D. M. 2014. Características zoométricas de equinos de raças definidas e não definidas criadas na região de Araçatuba, SP. Boletim de Indústria Animal 71:7.
R Core Team. 2016. R: A language and environment for statistical computing. R Foundation for Statistical Computing, Vienna, Austria. Available at: $<$ https://www.R-project.org/>. Accessed on: July 3, 2017.

Santiago, J. M. 2013. Caracterização morfométrica da raça Mangalarga Marchador. Tese (D.Sc.). Universidade Federal de Minas Gerais, Belo Horizonte.

Sobczuk, D. and Komosa, M. 2012. Morphological differentiation of Polish Arabian horses: multivariate analysis. Bulletin of the Veterinary Institute in Pulawy 56:623-629. https://doi.org/10.2478/ v10213-012-0110-5

Souza, G. L. 1998. Morfologia: seleção a toda prova. Revista da Associação Brasileira de Criadores de Cavalos Crioulos 40-44.

Torres, A. P. and Jardim, W. R. 1987. Criação do cavalo e outros equinos. Nobel, São Paulo, SP

Wright, S. 1921. Correlation and causation. Journal of Agricultural Research 20:557-585.

Zamborlini, L. C.; Bergmann, J. A. G.; Pereira, C. S.; Fonseca, C. G. and Carneiro, A. S. R. 1996. Estudo genético-quantitativo das medidas lineares de equinos da raça Mangalarga Marchador - I. Estimativas dos fatores de ambiente e parâmetros genéticos. Revista Brasileira de Ciência Veterinária 3:33-37. 